\title{
The Study of Quranic Teaching and Learning: United Kingdom Experience
}

\author{
Mohd Aderi Che Noh \\ Faculty of Education, National University of Malaysia, 43600 NUM Bangi, Selangor, Malaysia \\ Email: aderi7472@gmail.com \\ Ab. Halim Tamuri \\ Faculty of Education, National University of Malaysia, 43600 NUM Bangi, Selangor, Malaysia \\ Email: tamuri67@gmail.com \\ Khadijah Abd. Razak \\ Faculty of Education, National University of Malaysia, 43600 NUM Bangi, Selangor, Malaysia
}

Asmawati Suhid

Faculty of Educational Studies. Universiti Putra Malaysia, 43400 Serdang, Selangor,Malaysia. Email: asmawati@upm.edu.my

Doi:10.5901/mjss.2014.v5n16p313

\section{Abstract}

Al-Quran is the revelation to Prophet Muhammad (PBUH) started with the word "Iqra". Prophet (PBUH) had implemented five principles of al-Quran teaching and learning which his companions and the next generation follow until today. The model consist of Tilawah (good and fluency recitation), Tafahum and Tafsir (knowing and understanding the meaning), Tatbiq (appreciate and implantation of the teaching in daily life), Tahfiz (memorizing some verses for practice and reciting during prayer) and Taranum (reciting al-Quran with a good voice and proper song). In this part of the article, the main areas of discussion will be how the Qur'an is taught in the Muslim community in particular in their mosques, madrasas and community centres and hence their method of teaching and then how it is perceived by the audience i.e. the students, teachers and also parents. The study found that the teachers have been using a variety of strategies in implementing quranic teaching and learning, some teaching methods such as conventional and others reflect new methods taking into consideration the different abilities of the children. This style of teaching totally ignores the quality of recitation and teaching with the rules of Tajwid. This article will then lead to a conclusion, which will include some suggestions on how to improve the main curriculum and how the Qur'an should be taught.

Keywords: Quranic Teaching, Quranic Learning, Quranic teacher

\section{Introduction}

Quranic education is an obligation to every muslims. It is the responsibility of parents and teachers to help new generation in Quranic learning to become true muslim and better human being. Quranic learning started with learning Tajweed, which means learning how to pronounce and recite latter correctly. Tajweed can only be learned with a qualified Quranic teacher.

Abdullah Al-Qari (1988) asserts that the al-Quran must be learned from teachers' i.e by musyafahah and talaqi. Without any proper lessons with the experts, a person will unable to read the Quran properly and smoothly. A teacher who can recite the Quran with fluency and smoothly, and articulating every letter from its articulation point and giving the letter its rights and dues of characteristics will be considered as a model teacher who expert in al-Quran recitation (alGhazali, 1993). This is also consistent with al-Abrasyi (1969), which suggests those who wish to become a teacher of the Qur'an should know the consequences of reading the Quran and knowing the rules of reciting the Qur'an quickly and accurately. They should have sufficient capacity of knowledge to be taught to the students. 


\section{The Establishment Of Muslim Education In United Kingdom Toward Quranic Education}

Akbar S. Ahmed eloquently describes this new discovery of the British Muslim,

"In a crucial sense they are staring from the beginning... rejecting what their fathers stood for and what their elders spoke of...Each generation must now rediscover Islam for itself" (Akhbar Ahmad, 2001)

This brings us to looking at the establishment of Muslim education in the United Kingdom. In Britain, the establishment of Muslim education commenced during the 1960's with the 'Qur'anic School'. This was not an institution by itself but more of supplementary education in the mosques that the first generation of Muslim established for their children. Since the early days, Muslims began to rely on Imams imported from their home countries for religious services and for basic Islamic education for the younger generation. These lessons for primary and secondary school level pupils were teached by Imams to the pupils in the late afternoon after school hours or during the weekends (P. Lewis, 2002).

This effort of education for the Muslims have by now developed into the establishment of voluntary aided madrasas and Muslims faith schools across the United Kingdom, which follow the national curriculum but with Islamic studies, especially the teaching of the Qur'an, incorporated. The establishment of Muslim faith schools has been very successful since the late 1980's in the sense that there are currently over 100 independent and seven state-funded Muslim faith schools in the British education system. However, it is important to take note that the majority of Muslim children in the united Kingdom still attend British state schools and that the supplementary education is still the main link for a Muslim pupil to the teaching of the Qur'an. At this moment it seems that only three percent of the Muslim pupils in Britain attend Muslim faith schools or madrasas (Nasar Meer, 2007). .

This is the reason why the supplementary Muslim education and its Qur'anic teaching is the main focus for this study. It is the only way the majority of Muslim children across the United Kingdom can have access to the teaching of the Qur'an. This supplementary Muslim education utilizes a number of places to impart this knowledge during the weekend or after school hours. It is still common for the Muslim community in the United Kingdom to mainly use the mosque for such teachings, however, if that is not possible then a community centre or a local school is commonly hired for this purpose or the Qur'anic teaching may be imparted within the home of the imam (Peter Mandaville, 2007).

However, this supplementary education has in recent years been highly criticized by both Muslims and nonMuslims for their poorly educated Imams and out dated teaching skills (Martin Van Bruinessen, 2003). It has become very common to hear Muslims in the United Kingdom and in Europe demanding that their Imams should be better educated in the Islamic Sciences and have a better understanding of their respective European society (Amjad Hussain, 2007). Even though Islamic education in the United Kingdom has evolved successfully over the last forty years especially due to developments with regards the Muslim identity in Britain, it is still the supplementary Muslim education that is vital for the new Muslim generation, born and raised in the United Kingdom. It is therefore important to research the individual experience of how the Qur'an has been taught in these Qur'anic Schools.

\section{The Method Of Teaching And Learning Quranic Education In United Kingdom}

The Qur'an as Muslims understand it to be the direct speech of God revealed to the Prophet Muhammad through the Archangel Gabriel holds immense importance and status in their lives (Abdullah Saeed, 2008). Not a single home within any Muslim community will be without it. It is treated with utmost respect and dignity and every effort is made to ensure its sanctity. However, the main purpose of this part of the article is not to delve into the liturgy and virtues of the Qur'an from the Muslim perspective but to highlight how the Qur'an is taught and what methods are used specifically within the Western context and to be more specific within the context of the United Kingdom. Nor is it intended to delve into the different interpretations and sciences of the Qur'anic verses whether they are classical or modern interpretations. However, what will be highlighted here is a Qur'anic verse, which indicates the purpose of the Qur'an and then investigating and comparing this verse in terms of implementation within the context of the Muslim community.

In this part of the article, the main areas of discussion will be how the Qur'an is taught in the Muslim community in particular in their mosques, madrasahs and community centres and hence their method of teaching and then how it is perceived by the audience i.e. the students, teachers and also parents. This article will then lead to a conclusion, which will include some suggestions on how to improve the main curriculum and how the Qur'an should be taught.

It is stated in the Qur'an in Chapter Sad,

This is a blessed Scripture, which We have sent to you (Muhammad), so that people may think about its messages and 
those with understanding take heed (M. A. S. Abdel Haleem, 2010).

One does not have to be an exegete to understand and grasp this verse as it simply encapsulates how the Qur'an should be read, understood and practised. Further, to reinforce this position one may argue that the Prophet Muhammad himself followed these instructions and practically demonstrated them to his Companions as he was responsible to teach and clearly explain to his followers the book. Undoubtedly, Muslims read the Qur'an to obtain reward but does that fulfil the purpose, is mere reading sufficient? Or is the main objective defeated, which is to ponder and to implement, as the above verse implies.

Over the years however, different methods have been adopted for different age groups and the system and curriculum in mosques etc. has dramatically changed. This is mainly due to the exposure and teaching techniques, which teachers in this field have learnt and adopted from other sources such as government schools. Government teachers are provided and given different methods of how children can learn and what methods can be adopted. These same teachers then have the possibility to apply these methods in the mosques, which not only makes the session interesting, but more interactive and productive for the child. Categorically, the area of learning and teaching the Qur'an can fall into several categories; the first the mosque itself, secondly a community centre, which is hired out to the local Muslim community; thirdly a local school, fourthly at home or private tuition (Muslim, Sahih Muslim, 1998). In terms of the quantity of students, this will vary according to the population in each community.

However, with regards to the teaching methods, we have a fusion of different styles. Some teaching methods are conventional and others reflect new methods taking into consideration the different abilities of the children. As mentioned earlier, this method is very effective and also accommodates the children in their learning in this area of studies. For example, the conventional practice, which I like to use here rather than using the term 'old' or 'traditional' is a method which was imported from the subcontinent. This method of teaching, it could be argued is in total contradiction to our contemporary context and in addition, it could be further contended, that it is in conflict with the example of the Prophet Muhammad himself.

The typical classroom setting in a mosque would be that the students would sit on the floor in front of a bench and the teacher would sit in the front of the class. The teacher would call each student one by one and listen to his reading from the Qur'an and then set him more reading for the next day. Depending on the capability of the teacher, he would rectify the student's reading with correct pronunciation of each letter (Tajwid) or if he himself was unable to do this, then this would be left to the student's discretion.

However, the example of the Prophet Muhammad is quite different with regards to learning and teaching of the Qur'an. This is very explicitly explained in the Hadith of Sahih Muslim narrated by Ibn 'Abbas, which describes the way Gabriel would descend every night in the month of Ramadan. He would then read and teach the Qur'an to the Prophet Muhammad and then Muhammad would read it back to Angel Gabriel (Muslim, Sahih Muslim,1998). To further reinforce this, Al Suyuti in his Al-Itqan (Al Suyuti, Jalal al Din, 1991) and Al Nawawi in his Al Tibyan (Al Nawawi, Yahya, 2002) have given some examples of how the early generations would read and then further implement the Qur'anic verses.

From these examples, we can establish the importance of the Qur'an and its status in the eyes of the companions of the Prophet Muhammad. However, this example of the pious predecessors is not inherent in mindset of a great percentage of the Muslim community because they feel that it is sufficient for the children to complete the Qur'an in recitation by any means possible.

In addition, the most striking thing which I have observed is that the parents will thrive on this point that their children have completed the Qur'an many times, yet they do not understand a single word from it. We have many mosques and community centres and homes where the Qur'an is being repeatedly read and memorised yet the main purpose and the main essence of it still remains untouched. This point however does not discredit those organisations that teach the Qur'an in a systematic way.

However, even if the teaching was developed the mosques still do not have a curriculum or a unified programme with other mosques and organisations, especially with regards to the teaching method of the Qur'an. This is due to many factors; one of these factors is the different ideologies and sects within the Muslim community mentioned earlier in the article. This disallows having the possibility of a unified curriculum and syllabus.

The other factors are to do with which background you are from, even though you are resident in the United Kingdom. It has been argued by many of my colleagues that most mosques seem be run by people who are from the similar background linking them all to one tribe, family or clan emanating from their homeland. This ultimately brings along its consequences and implications because these same people will only allow an Imam who is from their own background. For arguments sake if an individual from a different group would apply for the role of Imam, then his application would be rejected. If not, then he would have a diminutive role within the mosque to discharge his duties. This 
ultimately leads to poor delivery of teaching and being very counterproductive in delivering to the students who have enrolled.

As previously mentioned, the main focus of the teaching Qur'an in the United Kingdom is primarily on the basic alphabet and thereafter the individual is encouraged to begin reading the Qur'an. This style of teaching totally ignores the quality of recitation and teaching with the rules of Tajwid. Unfortunately, this would ultimately defeat the main conditions of reciting the Qur'an. The Qur'an needs to be taught in such a manner which encapsulates the main purpose derived from the verse in Surah Sad. If this is done in this manner then the purpose of the Qur'an is achieved and hopefully rewarded. However, what is lacking is this focus on the purpose of the Qur'an, which therefore leaves the individual or in this case the student with no knowledge of what he/she is reciting. More focus is exerted on the quantity rather than the quality.

Furthermore, another point to consider here is the time constraints and the quantity of students in a Qur'an class. Due to the timetable, school time starts at $9 \mathrm{am}$ and ends at 3.30pm. By the time the children arrives home it is time to prepare and get ready for the mosque, which again differ with regards to opening times, some may even start at $4 \mathrm{pm}$, $4.30 \mathrm{pm}$ and $5 \mathrm{pm}$ and continue till $7 \mathrm{pm}$ or even 7.30pm. These two hours the child spends in the mosque, with other children learning the Qur'an who on average total 15-20 in numbers (sometimes even more). This means that the individual child will have spent no more than ten minutes with the teacher. It is safe to conclude here that the quality of teaching will be low, especially if you have limited time and a large number of students since each individual needs to be taught according to their own ability.

In terms of the work given for the next day it is the responsibility of the parents to ensure that their children are regular and consistent with their work and they are also responsible to ensure that this is done at home prior to their child's arrival to the mosque the day after. However, through my own experience, there are a few concerned parents who ensure that their children perform and fulfil their homework but majority are totally oblivious to their child's Quranic education. It is seldom I have had parents approaching me to ask how their children are performing, which again reflects upon the understanding of the parents and how much interest they show for their child's welfare and education.

\section{The Pitfalls In Implementation Of Quranic Education In United Kingdom}

So far, the discussion above, I am sure from the perspective of others who share my thoughts, seems to argue that there needs to be a more unified system and curriculum in the United Kingdom. This would not only accommodate the children but also the adults and parents of the Muslim community in order to appreciate and fulfil the purpose of the Qur'anic verse in chapter Sad. However, what has been stated previously was focused on learning how to read the Qur'an. There is also a need to emphasise the memorisation, which is as I would argue a Muslim tradition. The art of memorisation existed and was a common trend in the pre-Islamic era and remained important after the advent of the Prophet Muhammad till today. Memorising from a young age benefits the individual long term and helps in memorizing any text whether in Arabic, English etc.

Accordingly, there seems to be separate classes for memorization in the United Kingdom. Depending on the locality, there may be a high demand and some of them may even start early morning before school for one hour then after school e.g. $5 \mathrm{pm}$ till 8pm 5 days or even 7 days of the week. The Muslim community today in Britain has many Huffaz (Memorizers) of the Qur'an. Each individual will perform Tarawih in the month of Ramadan in mosque, community centre, at home or maybe go abroad because of the huge demand for someone to lead the prayer. However, the pinnacle of this discussion is that main purpose of understanding the Qur'an and its implementation remains.

Through the light of the verse in chapter Sad it clearly states the purpose of the Qur'an in terms of recitation, pondering/reflection and paying heed. There is no doubt that there is reward in recitation but by fulfilling the rules of Tajwid, which Muslims believe is an act of worship itself. However, with regards to its implementation the mosques, community centres and schools in the United Kingdom, which as part of the educational policy impart the teaching of the Qur'an, need to consider the following:

1. To have teachers who are familiar with the social settings and background of the community, hence the wider community. This implies that the teachers are not from abroad and they should be familiar with the system and methods of teaching hence they should be fluent in English.

2. Teachers should be kind hearted and loving towards their students and be able to accommodate their student's needs.

3. Teachers should be familiar with students who have special needs as everyone has different abilities.

4. Parents need to show more responsibility and awareness towards their children's Qur'anic education.

5. Parents need to create a link with the teacher and work in tandem with the work set out for the child. 
6. The committees of the mosques regardless of the different ideologies are required to consider the welfare and future of their children's Qur'anic education and to put aside their differences, which is creating a great confusion amongst the Muslim youth and children.

7. The committees need to work in tandem and are required to unify a curriculum and syllabus, which can accommodate a child who moves from one mosque to another or from one city to another.

8. The committees also needs to ensure that students are rewarded for their achievements and given commendations on a regular basis and this can be done if all the teachers of an institute work in tandem and have regular meetings with parents and children to discuss their progress and work on any difficult areas where the child needs assistance.

9. Great emphasis needs to be exerted in understanding the Qur'an which is key for the child in order for him/her to develop and grow into a peace loving Muslim.

\section{Conclusion}

These suggestions are based upon personal experience as a researcher of Quranic Education in the United Kingdom. However, there has been a wide changes in certain areas of the country in regards to the teaching of the Qur'an. Certain organisations do have a system and to understand the Qur'an, they have text books which elucidate certain verses of the Qur'an, which makes it far more enjoyable then mere reading in a repetitive fashion. The introduction of online courses for the Qur'an and its sciences alongside recitation and TV programmes, have also proven to be profoundly affective for anyone willing to learn the Qur'an. As an individual, parent and teacher, in my opinion, if the Muslim community wherever they are, work in solidarity and are conscious of their children's welfare and future, focus on this one verse of the Qur'an in chapter Sad, then I am optimistic there is a bright future . It is stated in the Qur'an. This Quran does show the straightest way.

\section{References}

Abdel Haleem M.A.S (2010). The Quran: English Translation. Oxford University Press. 17.9

Abdullah al-Qari Haji Salleh. (1988). Kursus qari dan qariah. Kota Bharu: Pustaka Aman Press Sdn. Bhd.

Abdullah Ishak. (1995). Pendidikan Islam dan pengaruhnya di Malaysia. Kuala Lumpur: Dewan Bahasa dan Pustaka.

Abdullah Saeed. (2008). The Qur'an, (London: Routledge), pp.22-34.

Akbar s. Ahmed, Islam Today, (London: I. B. Tauris), 2001, p.234

Al Nawawi, Yahya. (2002). Al Tibyan fi Adab Hamalat al Quran, (Beirut Lebanon: Muassasa al Risala,), p.78-94

Al Suyuti, Jalal al Din. (1991). Al Itqan fi c Ulum al Qu'ran, (Beirut Lebanon: Dar al Kutub al cllmiya), p.388-389.

Al-Abrasyi, Mohd Athiyah. (1969). Al-tarbiyah al-Islamiyah wafalasifatuha. Kaherah: Isaa al-Bab al-Halabi

Al-Ghazali, Muhammad. (1993). Kaifa nataamul maaal Quran. Kaherah: Dar al-Wafa'

al-Nawawi Yahya. (2002). Al-Tibyan fi Adab Hamalat al-Quran. Beirut Lebanon: Muassasa al-Risalah. p 78-94.

al-Sayuti, Jalal al Din. (1991). Al-Itgan Fi Ulum al-Quran. Beirut Lebanon: Dar al-Kutub al-IImiya. P 388 -389

Amjad Hussain. (2007). Saving the Crisis of Islam in Higher Education, Journal of Beliefs and Values, Special Islam Edition, Number 2, pp.267-273.

Ghazali Basri. (1991). Pendidikan Islam dalam sistem pendidikan kebangsaan: satu analisis. Jurnal Pendidikan Islam. Jilid 4: Disember.

Halim Na'am. (2005). Pelaksanaan j-Qaf. Prosiding Wacana Pendidikan Islam Siri ke-4. Fakulti Pendidikan: Universiti Kebangsaan Malaysia.

Kementerian Pelajaran Malaysia. (2005). Modul pengajaran pendidikan Islam. Kuala Lumpur: Dewan Bahasa dan Pustaka

M. A. S. Abdel Haleem,. (2010). The Qur'an: English Translation, (Oxford: Oxford University Press), 38:.29.

Martin Van Bruinessen, (2003), Making and Unmaking Muslim Religious Authority in Western Europe, ISIM

Mohd Salleh Lebar. (1992). Perubahan dan kemajuan pendidikan di Malaysia. Kuala Lumpur. Nurin Enterprise.

Nasar Meer. (2007). Muslim Schools in Britain: Challenging mobilizations or logical developments, Asia Pacific Journal of Education, Vol. 27, No. 1, , pp. 55-71.

Netherland-http://www.let.uu.nl/ martin.vanbruinessen/personal/publication/making_authority.h/, p.7.

P. Lewis, Islamic Britain, New York: I. B. Tauris \& Co. Ltd), 2002, p.56.

Peter Mandaville. (2007). Islamic Education in Britain: Approaches to Religious Knowledge in a Pluralistic

Society' in Hefner, Robert \& Qasim, Muhammad Zaman (eds.), Schooling Islam; the Culture and Politics of Modern Islam, (Oxford \& Princeton: Princeton University Press, p.230

Rosnani Hashim. (2001). Kurikulum pendidikan dari perspektif Islam dalam konteks pendidikan di Malaysia. Jurnal Pendidikan Islam. Jilid 9, Bil 4: November.

Sahih Muslim. 1988. Hadith no 6009. Riyadh Saudi Arabia: Darus Salam. p 1020 